Canadian University Music Review

Revue de musique des universités canadiennes

\title{
Male Nostalgia and Hollywood Film Music: The Terror of the Feminine
}

\section{Carol Flinn}

Volume 10, numéro 2, 1990

Alternative Musicologies

Les Musicologies Alternatives

URI : https://id.erudit.org/iderudit/1014883ar

DOI : https://doi.org/10.7202/1014883ar

Aller au sommaire du numéro

Éditeur(s)

Canadian University Music Society / Société de musique des universités

canadiennes

ISSN

0710-0353 (imprimé)

2291-2436 (numérique)

Découvrir la revue

Citer cet article

Flinn, C. (1990). Male Nostalgia and Hollywood Film Music: The Terror of the Feminine. Canadian University Music Review / Revue de musique des universités canadiennes, 10(2), 19-26. https://doi.org/10.7202/1014883ar

All Rights Reserved (C Canadian University Music Society / Société de musique des universités canadiennes, 1990
Ce document est protégé par la loi sur le droit d'auteur. L'utilisation des services d'Érudit (y compris la reproduction) est assujettie à sa politique d'utilisation que vous pouvez consulter en ligne.

https://apropos.erudit.org/fr/usagers/politique-dutilisation/ 


\title{
MALE NOSTALGIA AND HOLLYWOOD FILM MUSIC: THE TERROR OF THE FEMININE
}

\author{
Carol Flinn
}

\section{INTRODUCTION}

There is a certain currency to the idea that music can "take you back" radio capitalizes on this every weekend with "oldies" programs; entire films devote themselves to it (The Big Chill); rock music videos would seem to offer a return to the most basic and puerile of adolescent fantasies.

Hollywood film scores of the studio era (roughly 1935-1950) also used music to conjure forth lost, bygone periods. Think, for example, of the ability of "Tara's Theme" to evoke the antebellum South in Gone with the Wind, or "As Time Goes By" in Casablanca which sends us back to the idyllic days of Lisa and Rick's love affair in Paris. Entire genres have come to rely on music to present these lost epochs (historical dramas). But historical authenticity is not the most pressing subject at hand (for compositional styles often did not emulate those of the periods in which the films were set); indeed the "subject" at hand is the subject itself - in particular the male subject, whose own nostalgic past these scores repeatedly put into play.

The detective film of the $40 \mathrm{~s}$ - or film noir - offers a prime example of this for as a genre it is literally obsessed with the past. This reveals itself in titles such as Out of the Past and The Postman Always Rings Twice; in the commonly used flashback narrative structure of films such as Sunset Boulevard and Double Indemnity, and in the way in which pre-existing, past events - as is the case in many mysteries - have to be resurrected in order to "explain" the present or the film as a whole.

Like other Hollywood films of this period, film noir relies heavily on music to signal these lost moments: a song will often trigger the hard-boiled detective's reverie, and leitmotifs are usually associated with characters from within these memories. David Raksin's famous score for the film Laura perhaps best exemplifies this: the "Laura" character of this film is presumed to be dead, quite literally a thing of the past. Yet this does not deter the film's detective hero from falling hopelessly in love with her, and the theme song that bears her name is repeated compulsively throughout the film. 
The Laura example also indicates the centrality of woman's position within the past of film noir. Detective movies almost always feature a "duplicitous dame" who has betrayed or otherwise undone the hero, a woman who has left him with psychological scars or with marks of actual physical disablement: consider Phyllis Dietrichson (Double Indemnity), Elsa Bannister (The Lady from Shanghai) and Kathy Moffet (Out of the Past). Each of these women emerge from "out of the pasts" of their respective partners to destroy them, effecting a "return of the repressed" that terrifies these men as much as it attracts them.

Unlike other films of the period, films like Gone with the Wind or Casablan$c a$, which tend to romanticize the past, film noir ultimately poses the past as something that is always threatening to re-emerge - consider how the past "catches up" with the characters of The Postman Always Rings Twice and how the passage of time itself is something to be feared, something the protagonist must "beat" in films like D.O.A. and The Big Clock.

My present concern is with how music and femininity represent the burden of that unpleasant past in the 1945 film noir Detour. Detour also reinforces film music scholarship's own cliched association of music and femininity the score is considered "seductive," "emotional," "passive," and is usually disparaged for precisely these reasons.

But this is more than a matter of metaphor, and suggests something more disturbing and with a wider sphere of influence. For Detour dramatizes the sense of a "nostalgia gone bad." Femininity and music are first construed as a source of goods, and when this is proven inaccessible, they become objects of terror that are subsequently punished - both by the hero of these films and the male critics who respond to them.

There is a striking correspondence to this manoeuvre and the way that recent critical theorists have talked about music. I will refer to the work of Theodor Adorno, Roland Barthes, and Julia Kristeva, all of whom associate music with the idea of a lost utopian condition, one that Barthes and Kristeva and other psychoanalytically influenced theorists associate with femininity. For them music represents a pre-linguistic, pre-oedipal condition, an alternative way of generating meaning that finds its locus in the maternal body (literally, in the womb). This set of theoretical assumptions, like Detour itself, not only upholds the connection between women and music, but casts it into a regressive scenario of loss and restoration.

\section{SYNOPSIS}

Al Roberts narrates his story from a roadside Nevada diner. His flashback is prompted when "I Can't Believe That You're in Love With Me" is played on 
the diner jukebox. The song had been a favorite at a low-grade night club where Roberts had been employed as a pianist. In his words working there was like "heaven," chiefly due to his romance with Sue, one of the club's singers. When Sue decides to pursue a career in Hollywood, Al's heaven crumbles. Unable to live without her, he hitch-hikes West to join her.

His first significant ride is with a quirky man named Haskell, who tells $\mathrm{Al}$ about a female hitcher he had picked up earlier. Now in fighting off Haskell's sexual advances, this woman had left deep wounds visible on his hand. He calls her "the most dangerous animal in the world". Roberts nods in agreement. Later, Haskell takes a nap and Roberts is unable to wake him; when he opens the car door, his benefactor falls out, killing himself as his head hits a rock. In a panic, and convinced that the police would not believe his story, Al hides the body and drives on under Haskell's identity.

He picks up another hitchhiker, a woman named Vera (played by " $B$ " actress Ann Savage), who turns out to be the woman Haskell had picked up. She rejects Al's implausible story and, in order to prevent her from turning him in, they stay together in a Los Angeles hotel room. Vera is scheming and domineering; Roberts is morose and passive. The two bicker constantly. After one row in which Vera locks herself in the bedroom threatening to call the police, Roberts inadvertently strangles her by pulling the telephone cord from outside the room. With two freakish deaths on his hands, Roberts who never contacts Sue - leaves L.A. His flashback ends with him in the diner. As soon as he leaves, he is apprehended by the police.

\section{ANALYSIS}

Most criticism surrounding the film celebrates the "creative ingenuity" of its director. Andrew Sarris, for instance, refers to Edgar Ulmer as "one of the minor glories of the cinema . . . a genuine artist" and Peter Bogdanovich's interview with him reveals admiration of a quasi-religious nature (he was a "legendary figure," "miraculous"). Detour has been appreciated mainly as an expression of Ulmer's renegade "vision." One wonders what precisely there is about this "vision" which recent commentators find so appealing. Few critics have remarked on the film's soundtrack, even fewer, on its strange story.

Ernst Bloch has observed that detective narratives involve an Oedipal quest, a search for origins and original truth. But it also involves a search for lost mothers. Few detective films make this desire for the mother explicit (exceptions include White Heat and This Gun for Hire); most, like Detour, displace this desire onto younger women whose romantic affections, if once available, have - like the mother's - since proven impossible to win back (think again of Detour). Tania Modleski's feminist, psychoanalytic reading 
of Detour (Modleski 1982: 76-77) extends this line of thought. She notes how Roberts' relationships with women are like those of a child to his mother: Sue is the "good," comforting mother and Vera the "bad," punishing one [a division theorized by Klein: almost all of Klein's work revolves around the idea of "good" breast/"bad" breast ("good" mother / "bad" mother) - see especially Klein (1975)].

Modleski maintains that Al's predicament is the product of his overinvestment in the "heavenly" pre-oedipal phase that Sue represents. He cannot move beyond it or her. Modleski observes how Al's sullen response to Sue's announcement to go West (made after he reluctantly kisses her good night) suggests a child being abandoned by his mother, one who in turn abandons everything he has in order to regain her. Nostalgia moves him across the country.

Music is used as the "key" to restore Al to the fantasy of the benevolent mother. From the start, music is a sign of their past, launching Roberts into sentimental reverie as soon as "I Can't Believe That You're in Love With Me" plays on the jukebox. Their identities are bound to music, since Sue is a singer - defined by a soothing, melodic voice, and Roberts is a pianist. "I Can't Believe That You're in Love With Me" is "their" song and metonymically stands in for the union they once had. Motifs from the song appear throughout the film, most commonly when he fantasizes about Sue or prepares to call her. Initially it signifies a lost utopia for him, one whose reminder appears at his every turn.

Other music works in this same way: once when he telephones Sue a brief portion of Brahms' lullaby plays non-diegetically before dissolving into portions of "I Can't Believe That You're in Love With Me.' It seems to cradle the otherwise troubled protagonist.

Before Sue's departure we see $\mathrm{Al}$ at the club performing a piece by Chopin. Sue joins him at the piano and the two fantasize about his becoming a concert pianist. The selection of music in this scene is noteworthy since, beyond the Chopin here, identifiable classical music is used but once in the entire film. Its presence in this scene is "explained" by the fact that the characters are daydreaming about a career for $\mathrm{Al}$ as a concert pianist. It tells us, in other words, that at one time he had nurtured ambitions of entering the world of high art and classical music. This moment, however, is contained within the film's flashback, and so the hope it might have offered is already foreclosed.

The selection of Chopin also enforces the idea of looking backwards, of raiding history for utopian models of the future (much as Wagner turned to ancient Greece for blueprints of the "artwork of the future" and Adorno turned to the "pre-culture industry" works of Beethoven for examples of 
aesthetic integrity and wholeness). Chopin functions for Al Roberts in precisely this way, as an emblem of better times ( $\mathrm{Al}$ and the jazz player that "gets on [his] nerves"; jazz as the musical form of a decadent culture).

It is at this point that music starts to turn on the male subject. Just after Sue leaves him, Al abandons himself to these so-called "decadent" jazz forms in an astounding scene. He performs Brahms' Waltz (opus 39 no. 15) at the nightclub, looking terribly forlorn. It is immediately apparent that the pleasant refuge classical music had once offered has, like his girlfriend, left him. Things go from bad to worse. At first Al follows the melody of the waltz but then relinquishes himself to a bass-line improvisation that takes over the melody. In this way the "harmonious" pleasures of the earlier classical music are replaced by less stable boogie-woogie rhythms. One critic makes clear the connection between this musical performance and femininity, writing: "Bitter at his fiancée, Roberts would certainly like to punish her for abandoning him, as demonstrated in his punishment of the piano during his crazed interpretation of a Brahms waltz."

One might expect that if Chopin and Brahms - high art - finally represent displeasure to Al, a popular tune like "I Can't Believe That You're in Love With Me" would offer its pleasurable opposite. But this is not the case. Its title alone is charged with the idea of unlikelihood and improbability, and suggests that music is not going to provide $\mathrm{Al}$ with the kind of refuge he craves. The song's history is significant in this regard. "I Can't Believe ..." was a Tin Pan Alley song penned in 1927. Popular during the 30s, it was performed by a variety of people, including Count Basie, Earl Hines, Ella Fitzgerald and Bing Crosby. By the time of Detour's production in the mid 1940s, however, its popularity seems to have been played out. In other words, to 1945 audiences, "I Can't Believe ...'” was not a current hit, but one of the past. Its position in the film thus works along with the Chopin to highlight the regressiveness of Al's fantasy.

Music's threat grows. The strains of "Home Sweet Home" - a tune directly pitched to Al's nostalgic sensibility - plays mockingly as he enters the Los Angeles hotel room - what he calls his "prison" - with Vera. Music now reminds him of his distance from Sue - his "home" and mother. It becomes increasingly charged with the sense of loss and provokes his bitterness over this loss. This is most dramatically illustrated at the opening of the flashback.

Al's reaction to "I Can't Believe ..."' is nothing short of hysterical and it is clear that music bears the brunt of his hostility. In many ways "I Can't Believe ..." functions as an instrument set on his torture. It virtually overwhelms the text, appearing whenever Al thinks of Sue and often, when he doesn't (it is combined at one point with Vera's motif). Inescapable, the 
song and its variations immure $\mathrm{Al}$ Roberts within it. This ubiquity divests it of its initial utopian function; the song appears with such frequency that it can no longer simply signify Sue and Al's love.

True to the claims of psychoanalysis, Detour's score plays out a fundamental ambivalence of masculinity. For Roberts this is revealed in the good and bad objects that are assigned to Sue and Vera. At first, Vera appears to be defined as Sue's binary opposite: Sue sings and is defined by a pleasantness of sound; Vera doesn't and speaks harshly ( $\mathrm{Al}$ states: "Each word coming from her lips cracked like a whip"'). It is very significant, however, that once the musical utopia starts to fade, the distinctions between these "good" and "bad" women become less and less clear.

The score firmly establishes that Vera is not the non-musical opposite of Sue she initially appears to be. First, Vera has her own leitmotiv - a sort of non-lyrical equivalent of "I Can't Believe That You're in Love With Me" that is linked to Sue. Vera's theme is evoked at times when she is both out of sight and out of mind - suggesting again a flexibility of meaning and function. What is more, this leitmotiv is quite pleasant, a lush, romantic melody that mixes well with the film's other music (in some ways it is the most attractive motif of the film). And Vera's voice - though harsh in its delivery - is not in and of itself unpleasant. Combined, these auditory details reveal the implausibility of Vera being considered as completely "evil".

But the fantasy prevails. The film works arduously to construct Vera as the singly "bad," punishing maternal figure who is then punished. After all, she is "a dangerous animal" who inflicts wounds on Haskell's hand. This wound has special significance for $\mathrm{Al}$ since, as a pianist (and as a hitchhiker), this appendage is essential to his livelihood.

But $\mathrm{Al}$ and Haskell are not the only men whom Vera terrifies. We need now to return to the critics who have appreciated this film for its directorial "vision," for it seems to me that this "vision" speaks to a specific way of seeing and a certain nostalgic fantasy. Critics largely share Roberts' sense of a utopia-gone-wrong, and their negative projections inevitably fall upon Vera. The following passage is worth quoting at length in this regard:

Vera is quite possibly the most despicable female in movie history - even she admits she was born in a gutter ... The nicest compliment he can give her is "She had a homely beauty". The truest thing he can say is "Vera was just as rotten in the morning" . . . Her looks remind me of a vulture - not because she's ugly but because she appears to be thinking she'd like to rip you apart with her teeth and devour you piece by piece. Ian and Elisabeth Cameron correctly describe her: ". . . when she turns and looks at the 
camera, she has eyes so terrifying that one wonders how those who beheld her in the flesh managed to avoid getting turned to stone', (Peary 1981: 70)

Needless to say, a certain anxiety looms large as Danny Peary, the critic, extravagantly details this female "vulture's" abilities to disfigure ("she'd like to rip you apart with her teeth and devour you piece by piece"); he even evokes Medusa whose castrating "looks," of course, turn men to stone.

But more remarkable still is the manner in which Peary continues:

Even more terrifying than her face . . . is her voice. Rarely does she simply deliver a line; instead, she screams. She is loud, scratchy, intolerable. All the time. And worse when drunk ... It is fitting that Vera dies with a telephone wire around her neck, unable to finish her final sentence. The scene in which Vera is killed is doubtlessly the highlight of the film. Not only because it shuts Vera up once and for all, but because it exhibits Ulmer's most audacious use of the camera in the entire film ... (Peary 1981: 70)

Clearly Vera's greatest threat is her ability to produce sound, to "make noise." It is striking how eager Detour's male characters and critics are to "cut off" woman's speech, to strangle her sounds and music. (It also calls to mind Kristeva's conclusions about the maternal, musical realm of signification which she claims to be at work in the male avant-garde.) Even Sue's voice is subjected to this fear. When $\mathrm{Al}$ phones her prior to his departure, she is pictured wordlessly holding the receiver as if she were being silenced for having "spoken up" to him earlier. Now Al repeats her dialogue for her ("What? You're working as a hash slinger?'), a detail which demonstrates the force with which the film recuperates woman's sounds. The strangling of Vera, as Peary observes, does this with even greater violence.

Peary's contention that Vera's death is the best scene of the film is of course disturbing. But more than that, it is revealing. For it is clear that real-life commentators have come to adopt the same fantasies - the same "vision" - as Detour's wretched protagonist. The film's resentful nostalgia exceeds the text itself. The organizing force behind this fantasy is a masculine subjectivity that first esteems woman and then debases her for the control she is believed to have exerted over his happiness and his memories. In interviews, Edgar Ulmer expressed his full sympathy for the lead character; the identification is even more dramatic in the story of Tom Neal, the actor who portrays Roberts: sometime after Detour's release, he was imprisoned for murdering his own wife.

Detour's score, like those of so many Hollywood films of the 40s, works to create a sense of longing and nostalgia. Here it first signals a past stability for $\mathrm{Al}$, a memory into which he retreats to escape his present situation - he 
has, after all, lost Sue and killed two others. But the musical utopia fails to deliver. Instead of comforting him, music (like the woman) either leaves $\mathrm{Al}$ (the lullaby), annoys him (the sax), or changes function and "turns" on him ("I Can't Believe That You're in Love With Me").

As $\mathrm{Al}$ resigns himself to the idea that the past (and its feminine, musical charms - namely, Sue) cannot be regained, he projects his newfound resentment onto other female and musical figures (here, Vera). Vera is only superficially Sue's opposite, as the score indicates, but she is nonetheless punished - by Roberts and by male critics who are terrorized by the unpleasant sounds she makes.

Detour, like the criticism around it, finally blames the past for the problems and deficiencies of the present, a condemnation which is only possible if the past is giving heroically idealized dimensions to begin with. This has significant theoretical - and ideological - consequences since music and femininity - so involved with these anterior moments - end up being condemned as well.

But the score of Detour offers a condemnation of its own. There is a sense in which it seems to acknowledge the limitations of the fantasy it is supposed to represent for the male subject. Like Vera, it refuses to budge. It refuses to equip Roberts with the fantastic, hospitable past he wants. By doing this, it also chides film scholars who, like Al, buy into the belief that music in movies can do nothing but point backwards and seductively pine away.

\section{REFERENCES}

KLEIN, MELANIE.

1975: "The Emotional Life of the Infant", in Envy and Gratitude and Other Works 1946-1963. London: The Hogarth Press and the Institute of PsychoAnalysis.

MODLESKI, TANIA.

1975: "Film Theory's Detour", Screen, 23, No. 5: 72-79.

PEARY, DANNY.

1981: Cult Movies. New York: Delta Books. 